Article

\title{
Changes in Risk Perception of Seoul National University Students in Nuclear Power under Opposing Government Policy
}

\author{
Kyung-Shin Kim \\ Department of Environment \& Energy Engineering, Sungshin Women's University, Seoul 01133, Korea; \\ kyskim@sungshin.ac.kr; Tel.: +82-2-920-2740
}

Received: 15 June 2018; Accepted: 3 July 2018; Published: 6 July 2018

\begin{abstract}
This study examined how the perceptions of the risks from nuclear power have changed as the government policy has changed from nuclear-friendly to nuclear phase-out. In 2009, the concern about climate change was growing, and the government's new policy of "low carbon green growth" received wide public support (KNEA, 2014). In 2018, however, the present government is promoting a nuclear phase-out policy. Specifically, this study surveyed Seoul National University students in 2009 and 2018 in order to find similarities and differences in their perceptions of nuclear power risks and to suggest policy implications. The results of 2018 show that the perceptions of nuclear power risks increased, while that of the benefits decreased from 2009 under the opposing government policy. Specifically, the survey examined how the public support for nuclear power changed under the potential for climate-change and energy security in both 2009 and 2018. The negative perceptions of nuclear power were dramatically increased in 2018, however, and the preference for nuclear power was related more to energy security than climate change. The policy to expand or reduce nuclear power and renewable energy by imposing a new condition can be implemented only when the public acceptance of those energy sources has improved. Therefore, the government needs to define the objective reality of the risks and benefits that derive from each energy source, instead of managing the public acceptance by imposing a new condition. Also, the government needs to enhance the publicity about the public's acceptance of technology developments and government policy through consensus building with the related stakeholders.
\end{abstract}

Keywords: risk perception; nuclear acceptance; conditional support; climate change; energy security

\section{Introduction}

Background

Modern industrial society is a risky society that systematically produces huge risks $[1,2]$. Beck (1992) argues that the progress of civilization has amplified a new form of risk that cannot be controlled by the logic of the industrial society, and that fundamental reflection and changes in rationality are necessary. Industrial societies were expected to bring about technological development, followed by continuous growth and material affluence, but the progress of industrial societies has become a source of risk. In the modern industrial society, the risk was expressed by accident in areas that are close to the lives of people, such as nuclear power, chemical plants, aircraft, etc. Perrow (1984) explains that the cause of accidents in modern society lies in the complexity of the technology itself. High-risk technologies rely on complex, tightly coupled relationships, and the system in which they work is characterized by complexity [1,3].

Technology has inherent risks that are difficult to avoid. The definition, perception, and countermeasures of risks vary according to social context. It is not only by objective scientific facts, 
but also by the interests of the social groups involved in the risk that determine what to view as a hazard and how to define that degree and length. Individual factors acting on this process become inseparable in the social and structural context. In addition to the scientific uncertainty of risk, the difference in awareness and understanding of risks is not only social risk itself. In other words, risk is a substantive and objective phenomenon that is also socially constructed [1,4-6].

Risk in a modern society differs from risk in a previous society. Risks in past societies were objective and visible, but they are now socially constructed and subjective. What a certain society defines as a risk has also changed. Not only scientific analysis, but also the social consideration of risks was important to inform the public and to establish legal and institutional mechanisms to prevent the risks as much as possible [1]. The risk perception toward nuclear power is an example of the technological risks and systematic complexity of modern society. Because of the inherent nature of the risk of nuclear power, the government policy regarding the location of nuclear facilities has deviated over the years [7]. In response to the opposition of local residents, the government has encouraged resident participation and strengthened financial support to locations receiving dangerous facilities. In other words, the government has increased the risk acceptance of local residents by providing them with more benefits, rather than mitigating the objective risks of the nuclear power plants to be established [8]. What is notable here is that the risk perception of the public regarding nuclear power can be determined or changed in a specific context because it is socially constructed [9-12].

Nuclear energy has a variety of meanings in our society. In terms of economy and energy security, nuclear power plants have been regarded as a reliable energy source that provides abundant electricity at a low cost. Nuclear energy is also beneficial to the environment as a low carbon producer. In Korea, nuclear power accounted for $37.1 \%$ of the nation's electricity generation in 2016. After Lee Myung-bak was inaugurated as President in February 2008, he announced that "low carbon green growth (LCGG)" would be Korea's new national development paradigm in August 2008. The current Korean government has defined nuclear energy as the cornerstone of LCGG. The First Basic Plan for National Energy (2008-2030), which was issued in August 2008, aimed to expand Korea's nuclear capacity from $24 \%$ in 2008 to $41 \%$ in 2030 , and nuclear-electricity generation from $36 \%$ to $59 \%$ during the same period. In addition, the Fifth Basic Plan for Electricity Demand and Supply (2008-2024), issued in 2010, aimed to increase the share of nuclear electricity generation from $31.4 \%$ in 2010 to $48.5 \%$ in 2024. Four to six more reactors need to be constructed to fulfill the goals of the Basic Energy Plan by 2030 [13].

Nuclear energy is regarded as the key to meeting GHG reduction targets in Korea, since energy use accounts for by far the largest amount of its GHG emissions, at almost $85 \%$. Among the energy-related sources of GHGs, energy transformation was the largest, at over 37\% in 2016. Nuclear energy is expected not only to satisfy Korea's increasing electricity demand, but it will also help achieve the GHG reduction target. The Korean government has also promoted the export of nuclear power plant technology; such as what was transacted with UAE in 2009. Accordingly, Korea has come to enjoy the position of nuclear power-plant exporter [14]. The Korean public's support for nuclear power was relatively high until the Fukushima accident occurred. The Korea Nuclear Energy Agency started conducting an annual public opinion survey in 1993. In November 2010, almost 90\% (89.4\%) supported the notion that nuclear power was necessary, $45.9 \%$ supported the additional construction of nuclear power plants, and $43.0 \%$ supported maintaining the current levels of nuclear power in Korea. At that time, the national support for nuclear power generation was close to $90 \%$ [15]. In fact, the expansion of the nation's industrial activities, which is based on the low-cost generation of electricity by nuclear power, and the export of nuclear power plants stand for growth, while the low emissions of carbon dioxide from nuclear power plants are a green feature [3,14].

Plans to expand nuclear energy in Korea have changed since the aftermath of the Fukushima accident. Since the Fukushima accident in March 2011, many countries have shown significant changes in their nuclear policy. There has been a shift in Japan, Germany, Italy, and Switzerland. In Japan, all of the nuclear power plants in operation have been shut down, and efforts are being made to 
form an optimal mix of energy [14]. However, South Korea has consistently maintained its policy of strengthening safety management of nuclear power plants, regardless of the Fukushima accident. Environmental groups that want nuclear phase-out policy and experts have been at odds over the need to take energy mix while strengthening safety management [14]. During this conflict, the largest earthquake (5.8) occurred in Gyeongju on 12 September 2016. Residents around this region, which has a radioactive waste disposal site, have become more anxious.

In the 9 years since 2009, however, things have changed a bit. During Moon Jae-In's presidential campaign early 2017, he pledged to phase out coal and nuclear energy, mainly due to the public's growing concerns about air pollution and nuclear safety [15]. In their place, Moon vowed to increase the share of renewable energy to up to 20 percent of the total electricity generation by 2030. After taking office, Moon reconfirmed his campaign promise in a speech to mark the permanent shutdown of Kori-1, which went into operation in 1978 and was South Korea's oldest commercial nuclear reactor. In July, he permanently shut down the Kori-1. The construction of Shin Kori-5, 6 was suspended, and a public debate committee decided that the citizen jury would make a judgment after collecting public opinion for up to three months. Moon announced in October 2017 that he would resume the construction of two nuclear reactors in response to public opinion favoring the resumption [15].

On the surface, this decision might be seen as a direct contradiction to Moon's nuclear phase-out policy; however, this deliberative democratic action will have a complicated effect on South Korea's long-term energy policy. The majority of the respondents, ironically, supported the renewal of construction on the two plants and the simultaneous scale-down of nuclear-power generation. Such an eclectic decision by the citizens will help to manage the sharp conflict between the pro- and anti-nuclear groups, while giving some degree of domestic legitimacy to Moon's long-term energy road map for a gradual nuclear phase-out. Korea is the fifth-largest producer of nuclear energy in the world, with its 24 reactors generating about a third of Korea's electricity.

This paper aims to explain the change in the public acceptance of nuclear power under the conflicting government policies from the perspective of the social construction of risk perception. In 2009, the concern about climate change was growing, and the government's new policy of "low carbon green growth" received wide public support. It was in the context of this new emphasis that nuclear energy was reevaluated as an important clean energy source. In that time period, the government framed nuclear energy as a solution to the ongoing climate change problem and an important contributor to the green-growth goal in order to promote nuclear-friendly policies and increase social acceptance of nuclear power plants. Similar studies have shown that the public's perception of nuclear power will change when new conditions are given in terms of nuclear energy in response to climate change and as an alternative to future stable energy sources [16]. In 2013, two years after the Fukushima accident, there was still a growing consensus in the UK to choose nuclear power as a response to climate change and as a stable source of energy. It is not clear why British people did not change their risk perception of nuclear power. However, it was thought that the relatively safe geographic conditions of the United Kingdom (UK) were unlikely to cause large nuclear accidents due to tsunamis or earthquakes [17]. There is a comparative study comparing the Japanese people's perception of nuclear energy before and after the Fukushima accident with the above analysis framework of the British case [16]. As in the UK, given new conditions, the support rate in Japan has increased slightly, but the distrust of the entire nuclear policy has increased significantly since the accident [4].

In 2018, however, the present government is promoting a nuclear phase-out policy, in opposition to its predecessor in 2008. This study compared the acceptance of nuclear power among university students between nine years ago, when the government was actively promoting the construction of nuclear power plants, and now, when the government is pursuing a nuclear phase-out policy. It also tested whether such change in social context would influence the public acceptance of nuclear power. The study adopted the analysis tools of Poortinga et al. [18-20], who studied a similar change in the public acceptance of a social issue in British society. 


\section{Method of Study}

\subsection{Procedure}

This survey was administered to students at Seoul National University to find out how their perceptions of the risks from nuclear power changed from 2009, when the green-growth policy positively influenced the public perception of nuclear power, to 2018, when the government promoted a nuclear phase-out policy. The researchers recognize that studies sampling only university students have limitations when making generalizations. Although a survey was conducted on a somewhat limited group of SNU students, the survey on them is meaningful because it was conducted on university students. These students in their 20s may not be socially influential at the moment, but they are the group that will be the fastest to advance into the decision-making process in the future generations. Therefore, the results of their investigations are meaningful in that they can judge the future direction of policy decisions. Accordingly, the results of this survey will be helpful in predicting the government's future policy-making trends.

Using a quota sampling method, the survey sampled 100 undergraduates at SNU's Gwanak campus in each of the two years. The sample sizes are relatively small, and this means that the margins of error are between $6 \%$ and $10 \%$. Because of the error in the survey results, it is meaningful to identify the overall tendency. The ratios of the sampled students are given by the college in Table 1.

Table 1. Sampling.

\begin{tabular}{ccccc}
\hline College & \multicolumn{2}{c}{ 2009 } & \multicolumn{2}{c}{$\mathbf{2 0 1 8}$} \\
\cline { 2 - 5 } & Participants & Ratio (\%) & Participants & Ratio (\%) \\
\hline College of Humanities & 14 & 14 & 11 & 11 \\
Business School & 6 & 6 & 6 & 6 \\
College of Education & 9 & 9 & 12 & 12 \\
College of Social Sciences & 13 & 13 & 13 & 13 \\
College of Art & 8 & 8 & 8 & 8 \\
College of Agriculture and Life Sciences & 10 & 10 & 9 & 5 \\
College of Human Ecology & 6 & 6 & 5 & 10 \\
College of Natural Sciences & 9 & 9 & 10 & 26 \\
College of Engineering & 25 & 25 & 26 & 100 \\
Total & 100 & 100 & 100 & \\
\hline
\end{tabular}

\subsection{Questionnaire}

The questionnaire was adapted from that of Poortinga et al. $(2006,2010)$ for the purpose of this study. It consists of four main sections. The first looks at climate change and nuclear power from a broad perspective, comparing these two with a range of other environmental and energy-related issues on the global and local scales. The second section specifically considers the attitudes towards nuclear power. The third examines attitudes towards climate change in more detail, and the fourth section looks specifically at attitudes towards the reframing of nuclear power as a solution to the climate-change problem. This final section contains questions that were designed to compare the perceived risks from climate change with those from nuclear power, as well as to discover the attitudes towards different proposals for electricity generation. The measurement indicators and methods of each section are explained in Table 2 and the actual questionnaire is given in the following section of the Appendix A.

For the first survey, two researchers distributed and later collected the self-administered questionnaires according to the quota sampling method at each college between 11 and 18 November 2009. In the 2018 survey, a total of 100 questionnaires were distributed and collected from 8 to 23 March. 
Table 2. Questionnaire.

\begin{tabular}{|c|c|c|}
\hline Aspect & Variable & Scale \\
\hline \multirow{4}{*}{ Demographics } & Gender & Nominal scale \\
\hline & Age & Nominal scale \\
\hline & Major & Nominal scale \\
\hline & Whether to take a class on environment & Nominal scale \\
\hline \multirow{6}{*}{ Perception towards nuclear power } & Need of nuclear power & 5 Likert scale \\
\hline & Safety of nuclear power & 5 Likert scale \\
\hline & Risks and benefits of nuclear power & 5 Likert scale \\
\hline & Pros and cons of additional construction & 5 Likert scale \\
\hline & Support for nuclear phase-out policy & 5 Likert scale \\
\hline & Energy security and nuclear phase-out policy & 5 Likert scale \\
\hline \multirow{3}{*}{ Perception towards climate change } & Severity of climate change & 5 Likert scale \\
\hline & Risks and benefits of climate change & 5 Likert scale \\
\hline & Preferences for nuclear vs. renewable energy & 5 Likert scale \\
\hline \multirow{3}{*}{$\begin{array}{l}\text { Nuclear power as a solution to } \\
\text { climate change/energy security }\end{array}$} & Additional construction as a solution to climate change & 5 Likert scale \\
\hline & $\begin{array}{l}\text { Support for additional construction of nuclear power } \\
\text { plants when safety is ensured }\end{array}$ & 5 Likert scale \\
\hline & Mix of energy sources & 5 Likert scale \\
\hline \multirow{2}{*}{$\begin{array}{l}\text { Perception towards nuclear } \\
\text { phase-out policy }\end{array}$} & Nuclear phase-out policy and energy security & 5 Likert scale \\
\hline & Support for nuclear phase-out policy & 5 Likert scale \\
\hline
\end{tabular}

\section{Results}

\subsection{Survey Results}

\section{Characteristics of Respondents}

The survey examined whether the experiences of the respondents, such as participating in environmental groups (including clubs), publicity, or educational programs on nuclear energy, or taking classes on the environment or energy had affected their perception of nuclear power (Table 3). In the 2009 survey, $96 \%$ of the respondents had not participated in environmental groups, including clubs, $80 \%$ had not participated in any publicity or education programs on nuclear energy, and $64 \%$ had not taken a class on the environment or energy. In the 2018 survey, $84 \%$ of the respondents had not engaged in environmental groups or clubs, $81 \%$ had not participated in any publicity or education programs, and $51 \%$ had not taken a class on the environment or energy. To sum up, in both surveys, none of these experiences or their major led to any differences in their answers to any of the questions.

Table 3. Characteristics of respondents.

\begin{tabular}{ccccccccc}
\hline \multirow{2}{*}{ Year } & \multicolumn{2}{c}{ Gender } & \multicolumn{2}{c}{ NGO Participation } & \multicolumn{2}{c}{$\begin{array}{c}\text { Education Program } \\
\text { on Nuclear Power }\end{array}$} & \multicolumn{2}{c}{$\begin{array}{c}\text { Environment/Energy } \\
\text { Class Experience }\end{array}$} \\
\cline { 2 - 9 } & Male & Female & Yes & No & Yes & No & Yes & No \\
\hline 2009 & $60 \%$ & $40 \%$ & $4 \%$ & $96 \%$ & $20 \%$ & $80 \%$ & $36 \%$ & $64 \%$ \\
2018 & $58 \%$ & $42 \%$ & $16 \%$ & $84 \%$ & $19 \%$ & $81 \%$ & $49 \%$ & $51 \%$ \\
\hline
\end{tabular}

\subsection{Perception of Nuclear Power}

The results of the 2018 survey on the need for nuclear power showed that $24 \%$ of the respondents were supportive, $53 \%$ were neutral, and $23 \%$ were against it. By comparison, in the 2009 survey $60 \%$ of the respondents were for, while $11 \%$ were against. However, in the survey of 2018 , significantly fewer respondents agreed to the necessity of nuclear power plants (Figure 1). Meanwhile, regarding the question on the safety of nuclear power, which was added to the 2018 survey, $64 \%$ of the respondents were negative, and when it comes to the safety of radioactive-waste treatment, $66 \%$ of them answered negatively (Figure 2). 


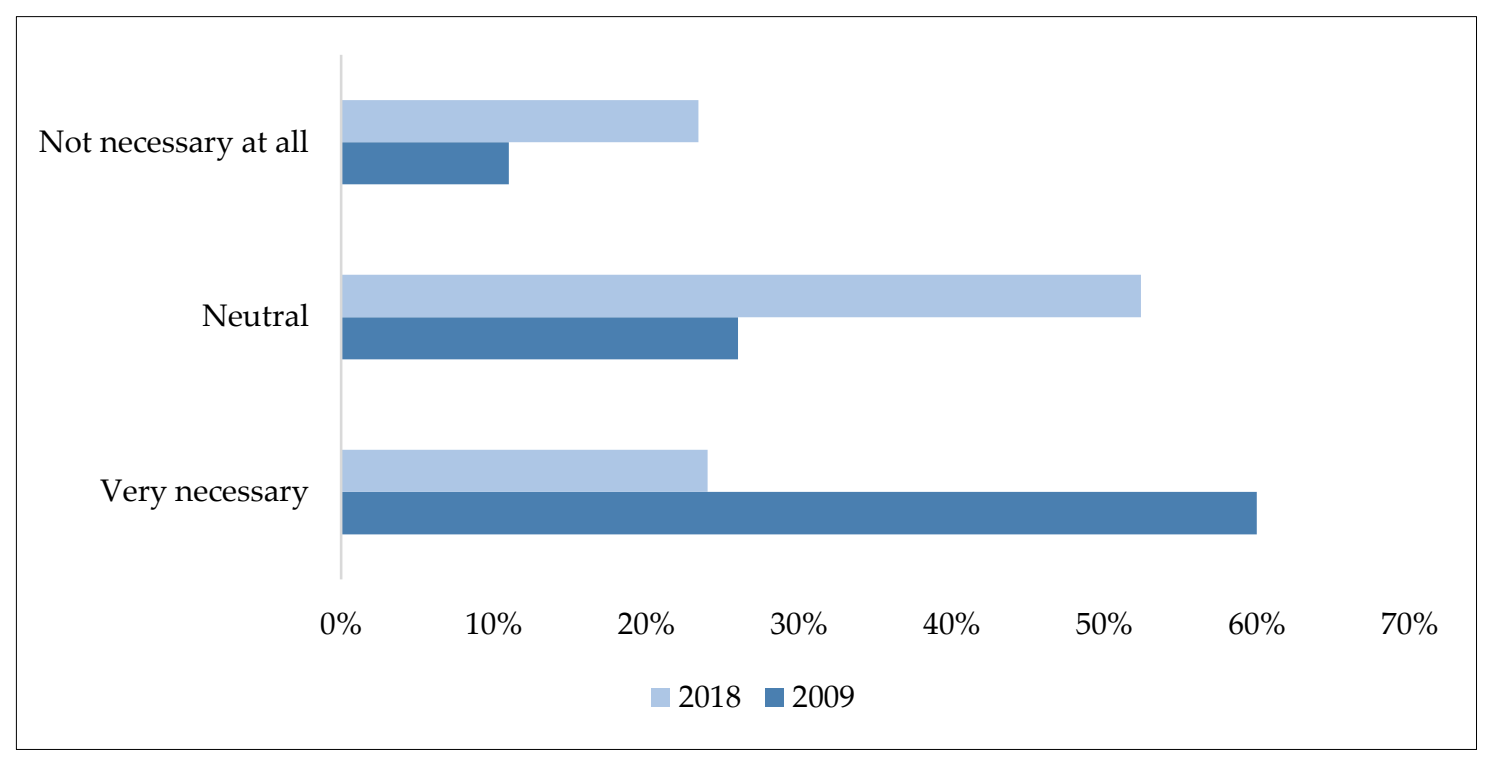

Figure 1. Attitudes towards necessity of nuclear power plants.

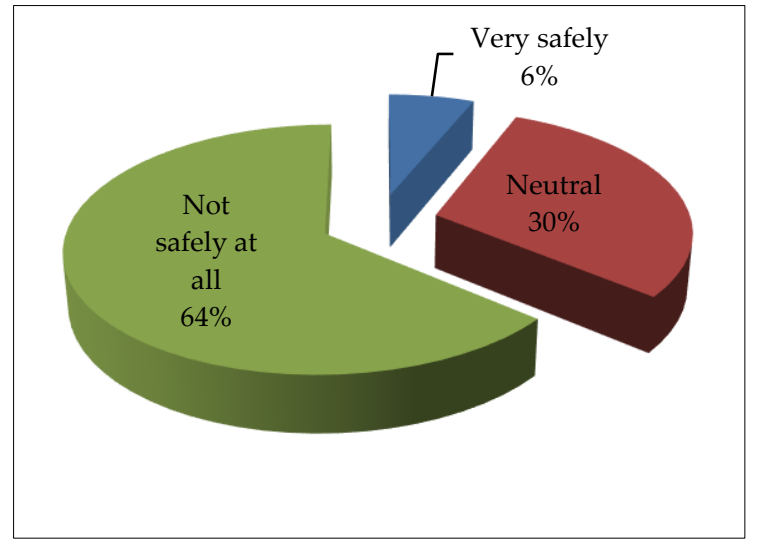

(a)

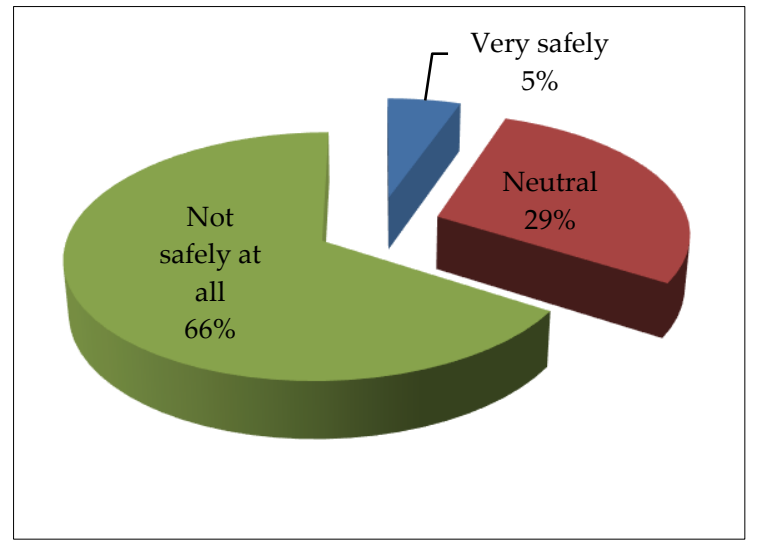

(b)

Figure 2. Respondent's position regarding safety of nuclear power plants (2018). (a) Safety of nuclear power plant. (b) Safety of radioactive waste treatment.

Regarding the additional construction of nuclear power plants, $45 \%$ of the respondents in the 2018 survey said, "Continue operating the existing nuclear power stations, and replace them with new ones when they reach the end of their life", while 38\% of them said, "Continue operating the existing nuclear power stations, but do not replace them with new ones"; and 6\% of them answered, "Shut down all existing nuclear power stations". In the nine years between the surveys, the ratio of respondents who agreed to the additional construction of nuclear power plants decreased significantly from $14 \%$ to $1 \%$, while that of those who opposed the additional construction of nuclear power plants after they reach the end of their life increased from $18 \%$ to $38 \%$ (Figure 3 ).

Regarding the question, "The risks of nuclear power outweigh the benefits", 34\% of the respondents in 2018 answered affirmatively. In 2009 it was 7\%, implying that the perception of risk to climate change increased significantly in the period. In addition, when asked whether the benefits outweighed the risks, the ratio of respondents who answered positively was $49 \%$ in 2018 , down from $75 \%$ in 2009. In other words, more people now put the risks over the benefits of nuclear power (Figure 4). When it comes to the nuclear phase-out policy of the current government, $44 \%$ of the 
respondents were positive, while $55 \%$ answered that the plan to increase the ratio of renewable energy to $20 \%$ by 2030 seemed to be less effective (Figure 5).

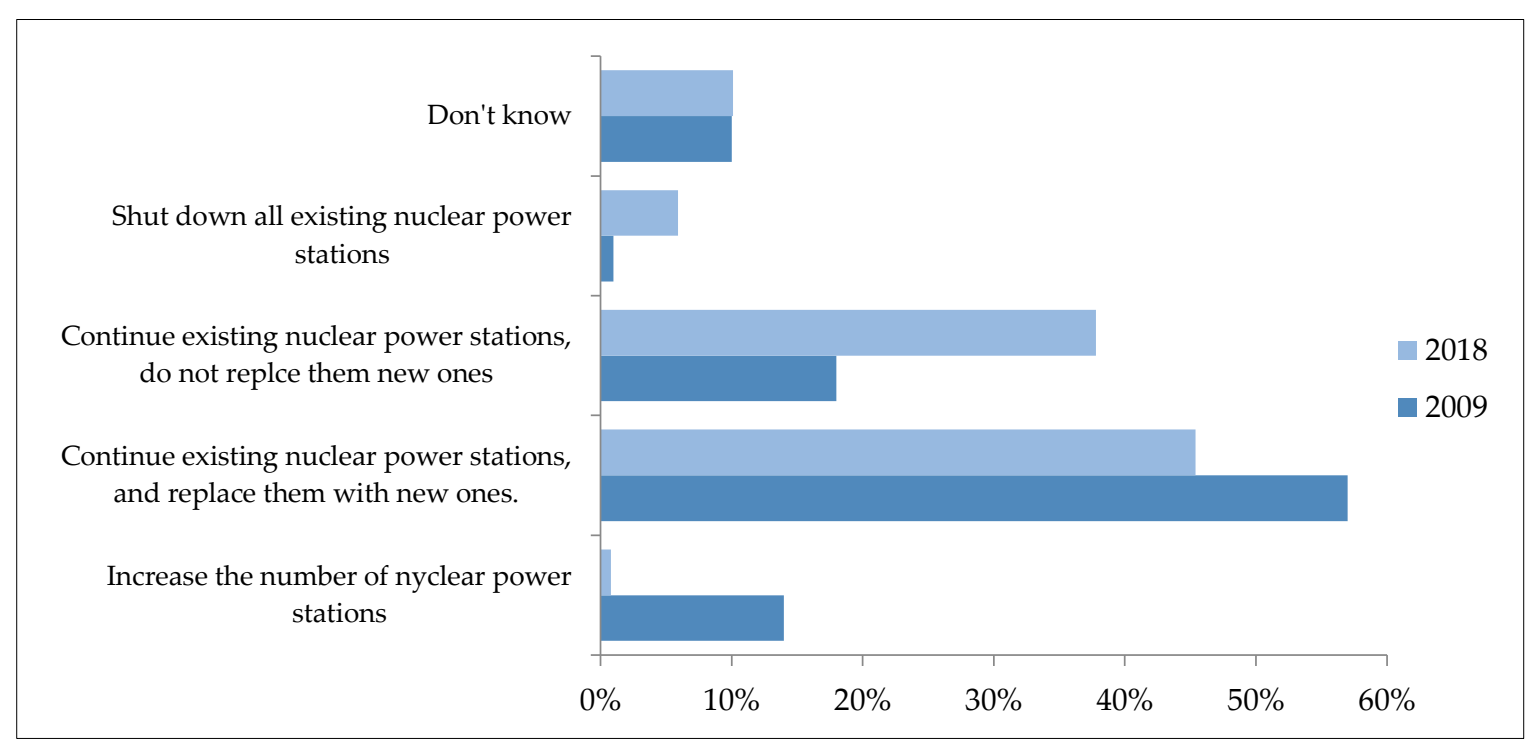

Figure 3. Attitudes towards additional nuclear power stations.

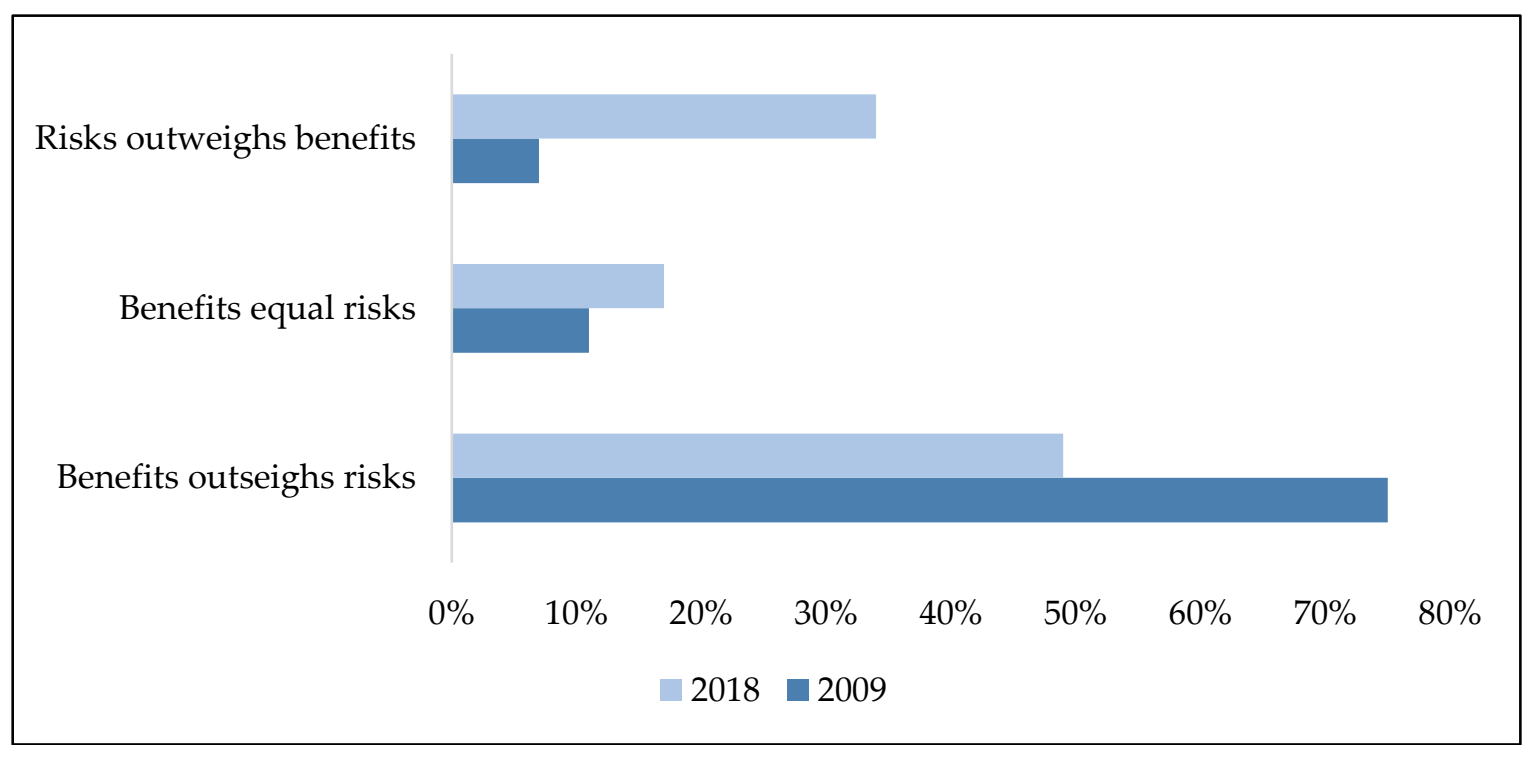

Figure 4. Risks and benefits of nuclear power. 
The plan to expand the ratio of renewable energy to $20 \%$ by 2030 seems to be less effective.

The government 's nuclear phase out policy poses a threat to energy security.

Supportive of unclear phase-out policies such as shutdown of Kori-1 nuclear power plant.

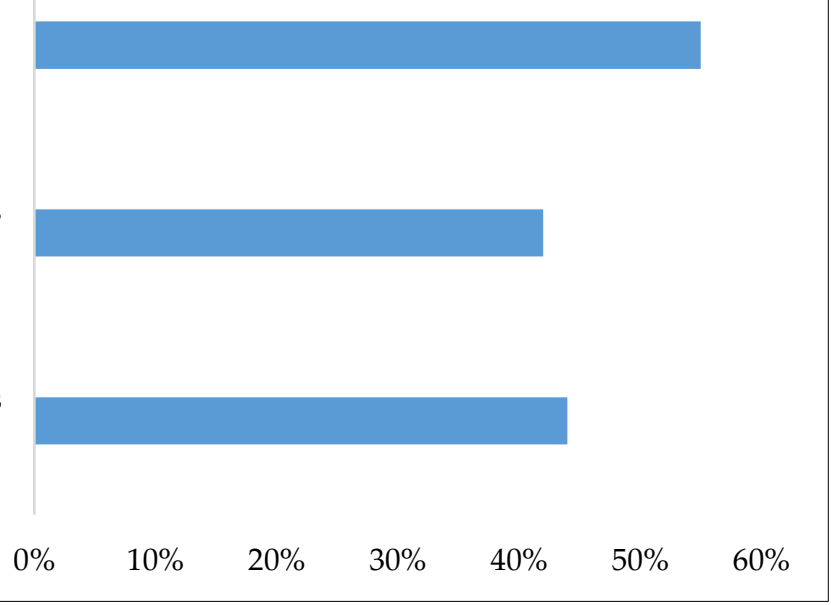

Figure 5. How people view nuclear phase-out policy.

\subsection{Perception of Nuclear Power with Respect to Climate Change and Energy Security}

It seemed on the one hand that the public was less worried about climate change and more interested in nuclear power. On the other hand, as the results of the surveys show, the opinion that the risks of nuclear power are greater than those of climate change increased dramatically from $17 \%$ in 2009 to $60 \%$ in 2018; and, the opinion that it is better to accept the dangers of nuclear power than to risk those of climate change decreased from 59\% in 2009 to 14\% in 2018 (Figure 6).

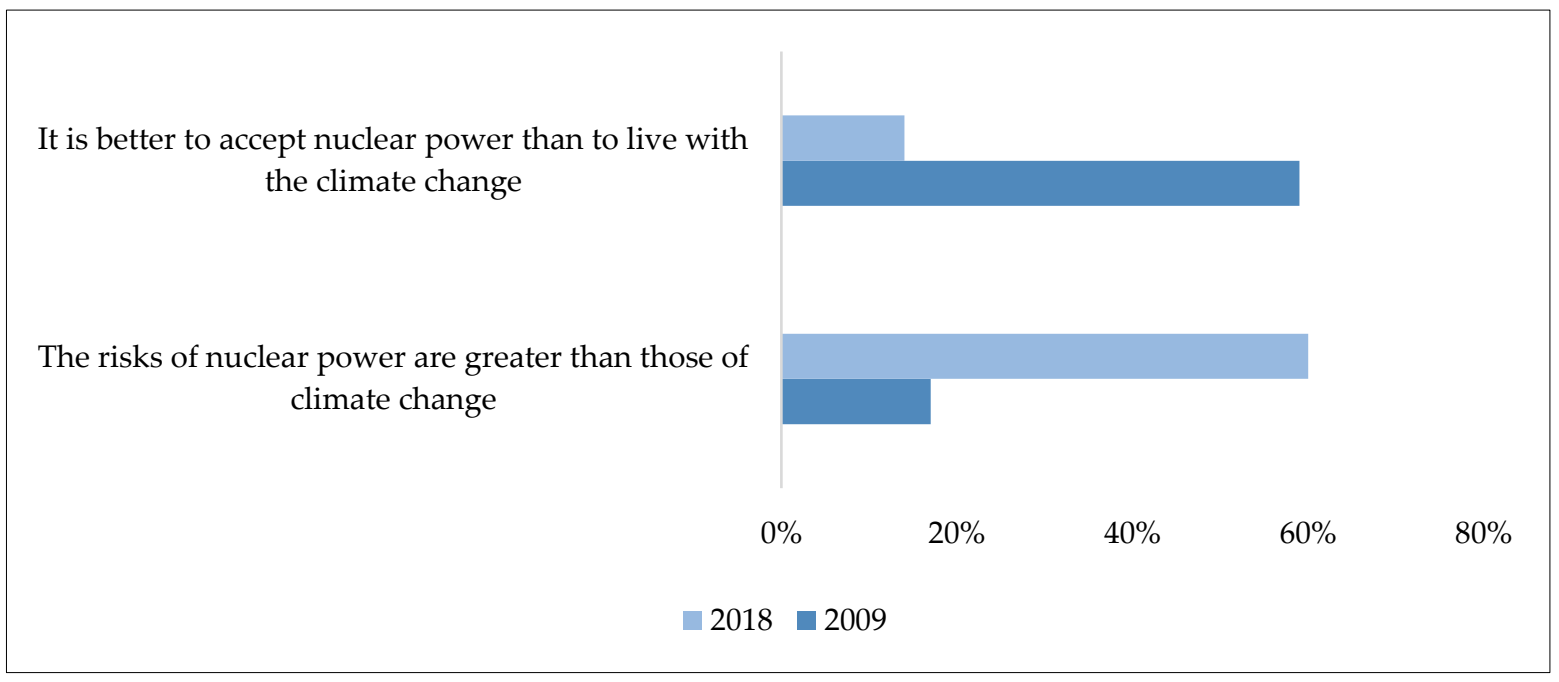

Figure 6. How people view risks of climate change and nuclear power.

Figure 7 shows the results of the surveys on preferred energy sources, assuming that nuclear power and renewable energy meet the domestic energy demand at the same cost. $84 \%$ of the respondents in 2018 and 80\% in 2009 preferred renewable energy sources. Meanwhile, fewer than 10\% in both 2018 and 2009 chose nuclear energy, showing their clear preference for renewable energy sources. 


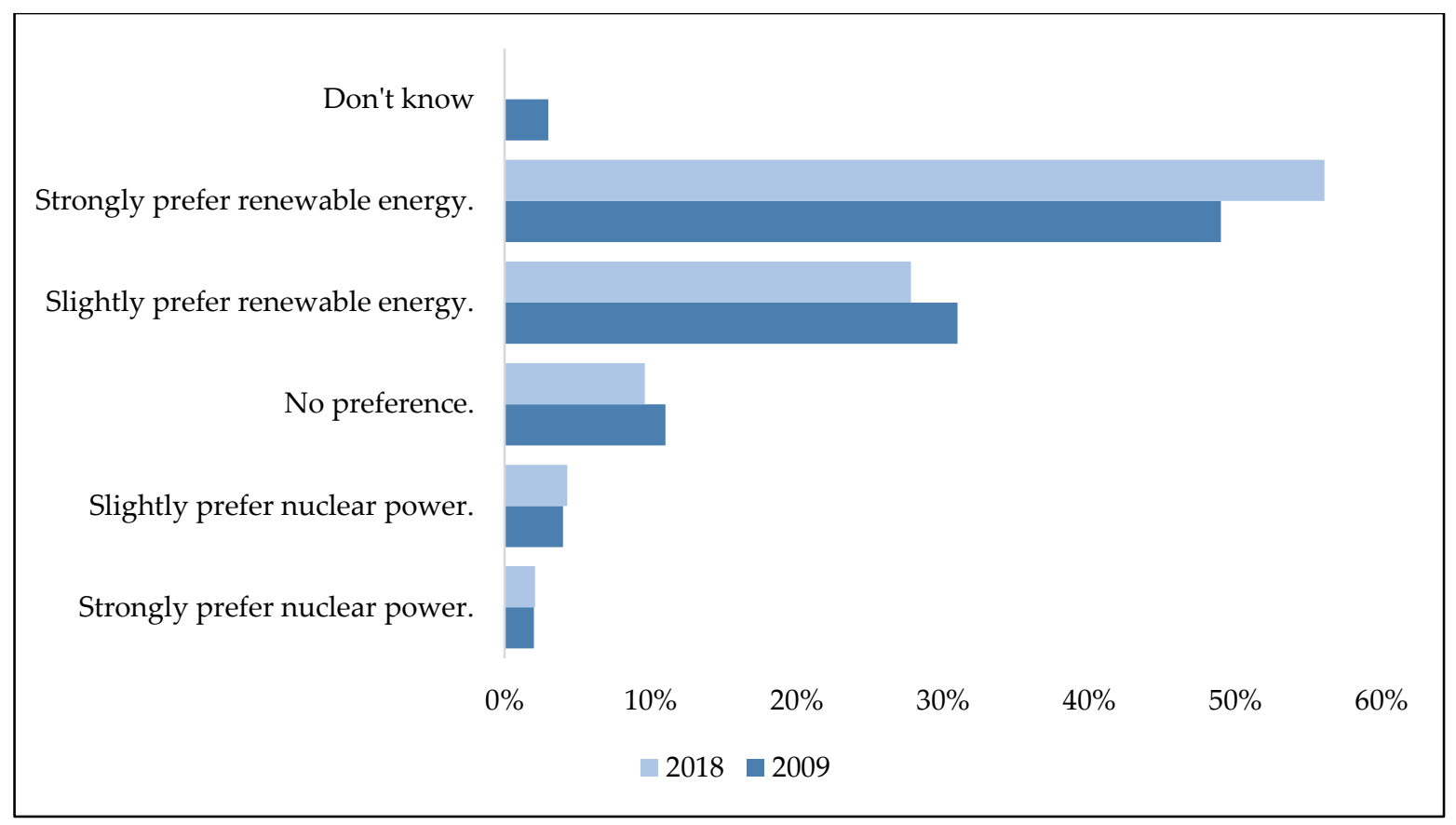

Figure 7. Preferences for nuclear power versus renewable energy.

Assuming that nuclear energy contributes to a certain purpose under new conditions, the survey examined the changes in public support for nuclear power under the conditions of climate change response and energy security. Provided that people who have a positive perception of nuclear power show unconditional support under any circumstances, a change in the support for nuclear power in a new context can be considered as conditional support. In the 2009 and 2018 surveys, the respondents who considered nuclear energy to be positive as a response to climate change outnumbered those who were positive about nuclear energy in the first place. Regarding the aspect of energy security, the respondents who answered that both nuclear power and renewable energy are required for a stable supply of electricity and that nuclear power is required to meet the energy demand outnumbered those who were positive about nuclear energy from the first. That means the public support for nuclear power is larger under the new conditions (Figure 8). To be specific, the ratio of respondents who agreed to the additional construction of nuclear power plants in response to climate change was higher than that of those who were positive about nuclear power from the start.

However, the respondents in 2018 were less positive about nuclear power with a higher risk perception of nuclear energy than those in 2009. They preferred nuclear power with respect to energy security rather than climate change response. Moreover, since the public concern about climate change has decreased considerably over the past nine years, the framing effect of nuclear power as a response to climate change has weakened. Although the overall negative opinion about nuclear power has increased over the past nine years, it is notable that people who argue that renewable energy sources are more effective than nuclear power in responding to climate change, and that nuclear power should not be considered as a solution to climate change before other energy alternatives are examined, outnumber those who were negative about nuclear energy from the start (Figure 9). 


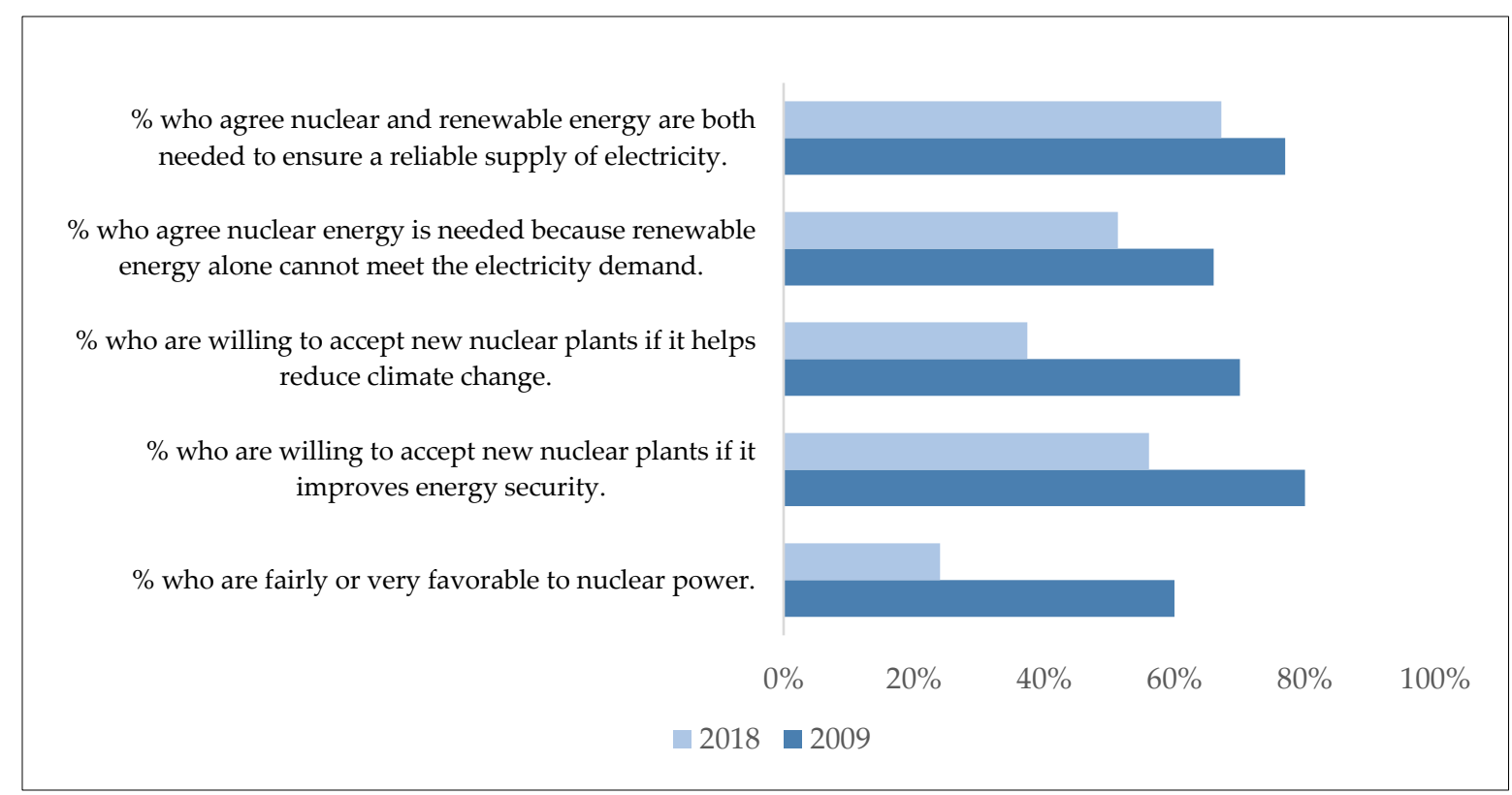

Figure 8. Conditional support for nuclear power.

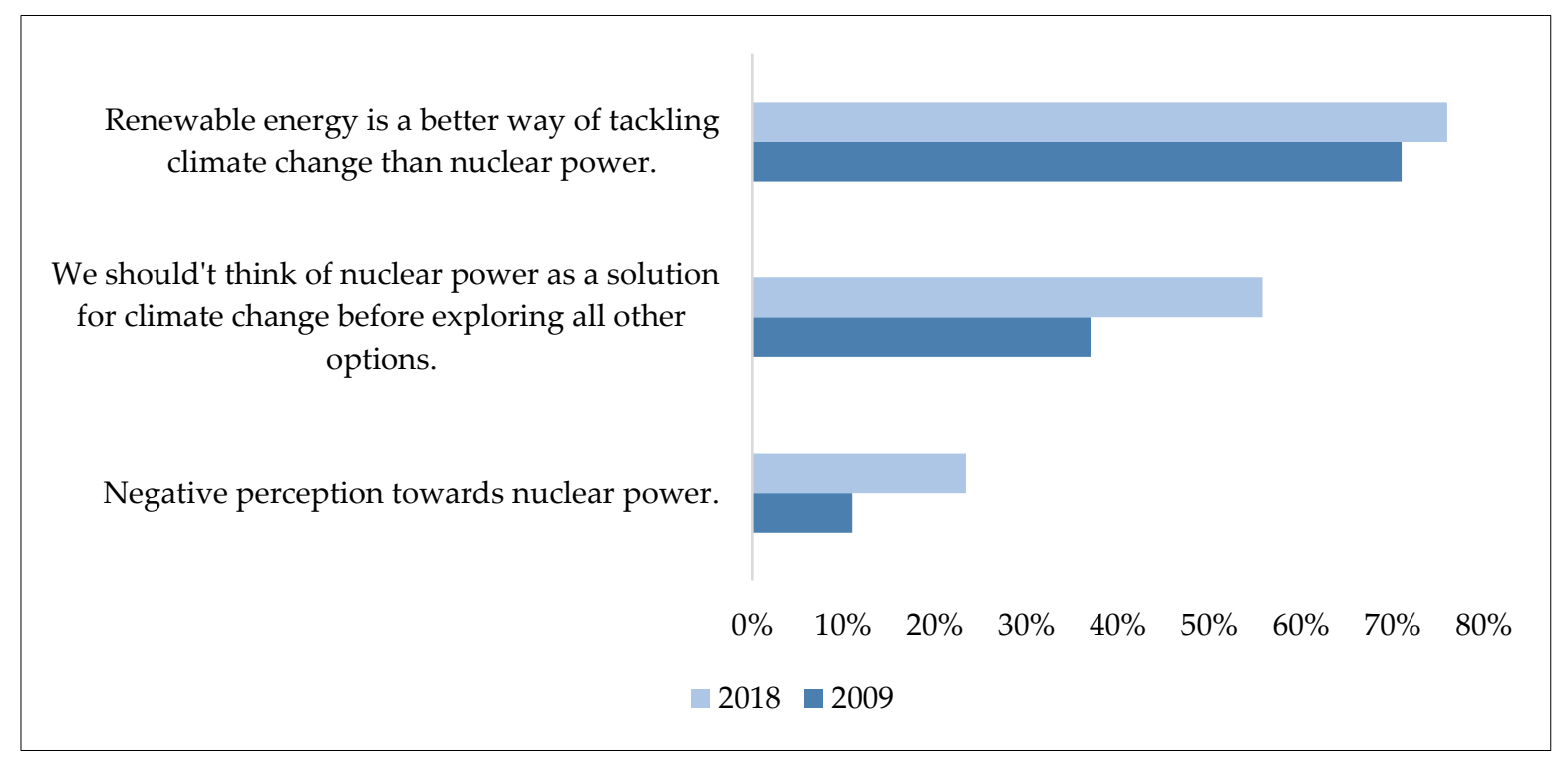

Figure 9. Negative attitudes on nuclear power.

\section{Conclusions}

This study assumes that even a slight change in how risks are socially constructed and expressed can significantly affect people's risk perception. Because the public concern about climate change and energy security was high in 2008, the Korean government introduced a policy to increase the public acceptance of nuclear power, promoting nuclear energy as a reliable electricity supply that does not contribute to climate change. However, the nuclear-friendly policy of 2008 was replaced by a nuclear phase-out policy in 2018 after the Fukushima accident in 2011 and the Gyeongju earthquake in 2016. Against this backdrop, this study examined how the perception of the risks from nuclear power has changed along with the change in government policy from nuclear-friendly to nuclear-free over the past nine years. Specifically, this study surveyed Seoul National University students in 2009 and 2018 
to find the similarities and differences in their perceptions of the risks from nuclear power and to suggest policy implications.

The students in 2009 considered climate change to be risky, while those in 2018 felt that nuclear power was more risky. In the 2018 survey, only one respondent answered positively regarding the additional construction of nuclear power plants, while the ratio had also increased of those who oppose new construction after the existing plants reach the end of their life. These results are in the context of the government policy that prohibits extending the life of old power plants. Meanwhile, the ratio of those who answered that the benefits outweigh the risks for nuclear power decreased significantly from $75 \%$ in 2009 to $49 \%$ in 2018; and, $64 \%$ of the respondents were negative about the safety of nuclear power, and $66 \%$ of them were also negative about the safety of radioactive waste treatment, implying that the objective risks of nuclear power plants need to be managed. To sum up, a comparison of the surveys from 2009 to 2018 shows that the public perception of the risks of electricity generation from nuclear power has increased, while that of the benefits has decreased.

The survey examined how public support for nuclear energy was affected by changed attitudes towards climate change and energy security. Regarding a change in support for nuclear power under new conditions as conditional support, the support for nuclear power with respect to climate change and energy security increased both in 2009 and 2018. That is to say, under the new conditions, the support for nuclear power increased, which was also shown in previous studies that were conducted in the UK and Japan. When compared to 2009, however, the negative perception of nuclear power increased dramatically in 2018, and the preference for nuclear power has increased more in terms of energy security than in response to climate change. In other words, although the energy security motivation was still effective, that of climate-change threat was less so. How these results were obtained is explained below.

(1) According to the study on Public Attitudes towards the Environment by the Korea Environment Institute (KEI, 2016), more than $70 \%$ of the public is aware of climate change, and $80 \%$ of them of its severity. As can be seen, the majority of the public is already well aware of the problem. In particular, they have been exposed to the government policies and environmental education provided within the framework of an appropriate response to climate change over the last nine years, and thus have become familiar with the issue of climate change in their daily lives.

(2) On the other hand, the frame of energy security was still an effective motivator. In this survey, the ratio of respondents who answered nuclear power is necessary for energy security was higher than that of those who were positive about nuclear power in the first place; and, many of them argued that nuclear power and renewable energy need to be used together to provide a stable supply of electricity. The majority of the public objected to an increase in the cost of electricity caused by a change in energy sources. They want to see the stable generation of electricity from economical, efficient, and eco-friendly energy sources. However, each energy source has its advantages and disadvantages, as well as its roles, and thus the government should develop a diverse energy mix instead of focusing on a single source of energy.

(3) As the change in risk perception of Seoul National University students has been witnessed in the spread of negative opinions about nuclear power over the last nine years, it seems that the negative portrayal of nuclear power by the government and its nuclear phase-out policy have worked well. Nevertheless, we should not forget the trial and error approach that the government used ten years ago when it managed the public acceptance of nuclear power as an effective climate-change response. Back then, the government strived to increase the public acceptance of nuclear power by managing the subjective risk perceptions of the people instead of by eliminating the objective risks of nuclear energy. The government now needs to straightforwardly acknowledge the economic feasibility and efficiency of nuclear power and eliminate its objective risks, instead of trying again to obtain public acceptance through framing the situation. In Korea, nuclear power was once at the center of economic development, but it is now considered a "social evil". However, we should not forget that it was, perhaps, inevitable 
to introduce nuclear power, which is economically feasible and efficient, when considering the lack of natural resources in the country. It is notable that the number of respondents who were in favor of the government's nuclear phase-out policy is less than that of those who were neutral. It means that the majority of the public has not fully agreed with the policy yet.

(4) The eighth demand-supply program in Korea can be summarized as "Moving away from nuclear energy; expanding new and renewable energy". Basically, this program is completely negative about nuclear energy and positive about new and renewable energy. However, it is also necessary to be careful about the eco-friendly frame for renewable energy. Therefore, the plan to expand its ratio to $20 \%$ by 2030 seems to be less than optimum. In fact, it is dangerous to rely heavily on these energy sources, which do not have enough infrastructure yet, only because they are eco-friendly. In the national energy plan, it is not reasonable to set the percent of nuclear energy because it is a means in the process of achieving the goal. The Energy Act articulates its purpose in Article 1 as "strengthening the energy supply and demand structure in a reliable, efficient, and eco-friendly manner". To that end, the government needs to consider the environmental conditions, and social and cultural factors, as well as the states of the economy and technology when determining the place of nuclear power plants in the national energy plan.

The policy to expand or reduce nuclear power and/or new and renewable energy sources by imposing new conditions can be realized only when the public acceptance of those energy sources is improved. They need to enhance the public understanding instead of manipulating the public into acceptance by imposing new conditions or changing policies. Also, the government needs to enhance the publicity about the public acceptance of technology developments and policies through consensus building with the related stakeholders.

The survey in this study was conducted on limited groups of SNU students. We recognize that studies sampling only university students have limitations when generalizing. The purpose of this study was to explore how public awareness of nuclear power would appear under opposing government policies. We thought that this effect could be expected, even though the sample was only university students. As it is targeted at limited groups due to cost and time constraints, it is expected that in the future a full-scale study will take place using citizens about changing their risk perception under opposing government policies.

Funding: This research received funding of Sungshin University Research Grant of 2017.

Acknowledgments: This work was supported by Sungshin Universtiy Research Grant of 2017.

Conflicts of Interest: The author declares no conflict of interest.

\section{Appendix}

Table A1. Risk Perception Questionnaire.

\begin{tabular}{ccl}
\hline Question Topic & Question ID & \multicolumn{1}{c}{ Description of Questions } \\
\hline $\begin{array}{c}\text { Perception } \\
\text { towards nuclear } \\
\text { power }\end{array}$ & 4 & $\begin{array}{l}\text { Do you think nuclear power generation is necessary or not? } \\
\text { Do you think nuclear power plants in our country are safe or not? } \\
\text { Do you think radioactive waste in our country is managed safely or not? } \\
\text { From what you know or have heard about nuclear power, which of } \\
\text { these statements, most closely reflects your own opinion? } \\
\text { To what extent do you support or oppose the building of new nuclear } \\
\text { power stations to replace those being phased out over the next } \\
\text { few years? } \\
\text { If the costs of supplying the Korea's energy needs were the same from } \\
\text { either nuclear power or renewable energy sources, which would } \\
\text { you prefer? }\end{array}$ \\
\hline
\end{tabular}


Table A1. Cont.

\begin{tabular}{|c|c|c|}
\hline Question Topic & Question ID & Description of Questions \\
\hline \multirow{6}{*}{$\begin{array}{c}\text { Perception } \\
\text { towards climate } \\
\text { change }\end{array}$} & 7 & $\begin{array}{l}\text { To what extent do you agree or disagree with each of the following } \\
\text { statements. }\end{array}$ \\
\hline & & The risks of nuclear power are greater than those of climate change \\
\hline & 8 & $\begin{array}{l}\text { It is better to accept nuclear power than to live with the consequences of } \\
\text { climate change }\end{array}$ \\
\hline & 9 & $\begin{array}{l}\text { I am willing to accept the building of new nuclear power stations if it } \\
\text { would help to tackle climate change }\end{array}$ \\
\hline & 10 & $\begin{array}{l}\text { We shouldn't think of nuclear power as a solution for climate change } \\
\text { before exploring all other energy options }\end{array}$ \\
\hline & 11 & $\begin{array}{l}\text { Promoting renewable energy sources, such as solar and wind power, } \\
\text { is a better way of tackling climate change than nuclear power }\end{array}$ \\
\hline \multirow{4}{*}{$\begin{array}{l}\text { Nuclear power } \\
\text { as a solution to } \\
\text { climate } \\
\text { change/energy } \\
\text { security }\end{array}$} & 12 & $\begin{array}{l}\text { Reducing energy use through lifestyle changes and energy efficiency is } \\
\text { a better way of tackling climate change than nuclear power }\end{array}$ \\
\hline & 13 & $\begin{array}{l}\text { We need nuclear power because renewable energy sources alone are not } \\
\text { able to meet our electricity needs }\end{array}$ \\
\hline & 14 & $\begin{array}{l}\text { We need a mix of energy sources to ensure a reliable supply of } \\
\text { electricity, including nuclear power and renewable energy sources }\end{array}$ \\
\hline & 15 & $\begin{array}{l}\text { If we had safer nuclear power stations, I'd be prepared to support new } \\
\text { ones being built }\end{array}$ \\
\hline \multirow{3}{*}{$\begin{array}{l}\text { Perception on } \\
\text { nuclear } \\
\text { phase-out } \\
\text { policy }\end{array}$} & 16 & $\begin{array}{l}\text { I am supportive of unclear phase-out policies such as shutdown of } \\
\text { Kori-1 nuclear power plant. }\end{array}$ \\
\hline & 17 & $\begin{array}{l}\text { The government's nuclear phase out policy poses a threat to energy } \\
\text { security. }\end{array}$ \\
\hline & 18 & $\begin{array}{l}\text { The plan to expand the ratio of renewable energy to } 20 \% \text { by } 2030 \text { seems } \\
\text { to be less effective. }\end{array}$ \\
\hline
\end{tabular}

\section{References}

1. Yun, S.J.; Park, H. The social construction and communication of the risk caused by oil spills: Centering on the media coverage on the voluntary work during the aftermath of the Samsung Heavy Industries-Hebei Spirit Oil Spill. ECO 2011, 15, 7-52.

2. Beck, U. Risk Society: Toward a New Modernity; Sage: New Delhi, India, 1992.

3. Kim, K.S.; Yun, S.J. A exploratory study on acceptability change of nuclear power as a responding solution to climate change as a result of framing effect and its policy implication. J. Environ. Pollut. 2010, 18, 91-129.

4. Aoyagi, M.; Tasaki, T.; Yoshida, A.; Kanamori, Y. Public Understanding of Risk-Risk Trade-Offs among Climate Change and Energy Option: Tsukuba, Japan; Research Group of Sustainable Consumption and Lifestyles; National Institute for Environmental Studies: Tsukuba, Japan, 2011.

5. Chung, J.B.; Kim, E.S. Public perception of energy transition in Korea: Nuclear power, climate change, and party preference. Energy Policy 2018, 116, 137-144. [CrossRef]

6. Lee, S.H. Risk and risk management in modern society: Theoretical discussion on the social construction of risk. J. Contemp. Soc. Cult. 2009, 29, 61-86.

7. Kim, K.S.; Yun, S.J. An analysis of risk/benefit perception and acceptability of a nuclear radioactive waste disposal facility placement in Buan and Gyeongju. Korea Assoc. Policy Stud. 2014, 23, 313-342. (In Korean)

8. Park, S.A.; Lee, J.H. Policy failures: Siting a radioactive waste disposal facility in South Korea. J. Environ. Pollut. 2005, 13, 63-98.

9. Yun, S.J.; Oh, E.J. A Study on the social construction of the nuclear power generation policy in Korea: Focused on the introduction processes of nuclear technology. J. Environ. Pollut. 2006, 14, 37-74.

10. Corner, A.; Vanables, D.; Spence, A.; Demski, C. Nuclear power, climate change and energy security: Exploring British public attitudes. Energy Policy 2011, 39, 4823-4833. [CrossRef]

11. Fischoff, B.; Slovic, P.; Lichtenstein, S.; Read, S.; Combs, B. How safe is safe enough? A psychometric study of attitude toward technological risks and benefits. Policy Sci. 1978, 9, 127-152. [CrossRef] 
12. Pidgeon, N.F.; Lorenzoni, I.; Poortinga, W. Climate change or nuclear power: No thanks! A quantitative study of public perceptions and risk framing in Britain. Glob. Environ. Chang. 2008, 18, 69-85. [CrossRef]

13. Yun, S.J. Nuclear Power for Climate Mitigation? Contesting Frames in Korean Newspapers. Asia Eur. J. 2012, 10, 57-73. [CrossRef]

14. Kim, B.D.; Yun, S.J. Changes of nuclear promotion strategies in South Korea after the Fukushima nuclear accident. Korea Soc. Soc. Sci. 2013, 48, 509-529.

15. Korea Nuclear Energy Agency. A National Survey of Nuclear Power; Korea Nuclear Energy Agency: Seoul, Korea, 2014.

16. Kim, K.S.; Cho, H.S. Changes in risk perception regarding nuclear power following the Fukushima nuclear accident. J. Environ. Pollut. 2015, 9, 145-172. [CrossRef]

17. Song, B.J. Policy making: Political decision making vs. Administrative decision making on the nuclear phase-outs policy. Korean Soc. Public Adm. 2018, 2, 1-29.

18. Poortinga, W.; Pidgeon, N.F.; Lorenzoni, I. Public Perceptions of Nuclear Power, Climate Change and Energy Options in Britain: Summary Findings of a Survey Conducted during October and November 2005; Tyndall Centre for Climate Change Research Understanding Risk Working Paper 06-02; University of East Anglia: Norwich, UK, 2006.

19. Bickerstaff, K.; Lorenzoni, I.; Pidgeon, N.F.; Poortinga, W.; Simmons, P. Reframing nuclear power in the UK energy debate: Nuclear power, climate change mitigation and radioactive waste. Public Underst. Sci. 2008, 17, 145-169. [CrossRef] [PubMed]

20. Poortinga, W.; Aoyagi, M. Public Perceptions of Climate Change and Energy Futures before and after the Fukushima Accident: A Comparison between Britain and Japan; Risk Working Paper 01-2013; Elsevier: New York, NY, USA, 2013.

(C) 2018 by the author. Licensee MDPI, Basel, Switzerland. This article is an open access article distributed under the terms and conditions of the Creative Commons Attribution (CC BY) license (http:/ / creativecommons.org/licenses/by/4.0/). 